\title{
Caderno de Poesias III
}

Claudia Pastore ${ }^{1}$

\section{RED}

Meu cabelo vermelho

Cresceu e se perdeu

Pelo tempo

Carregado pelo pranto

Dos dias

Que não foram grandes,

Que não foram sóis,

Que não foram poesia.

Meu cabelo vermelho

Mudou de cor, enfraqueceu.

Fruto de pensamentos

Maduros, pouco inconseqüentes.

Pouco ingênuos,

Desprovidos de sonhos.

Meu cabelo, pouco e pequeno,

O sol queimou e o vento

Secou.

Eu fui,

Mas ele ficou. 
ENSEADA

O sol retina do olhar

Apagou a consciência

Enganada de sonhos,

Deixou que o sal

Queimasse os olhos

Impedindo o real

Exagerado da paisagem

Bonita do mar.

Um homem - do mar -

Talvez - pele queimada

E olhar desatento a tudo,

Compôs a paisagem verdade

Com natural veemência,

Maestria das figuras

Que não são nada,

Simplesmente, porque

São tudo. 
GUERNICA

Lutar para estar

Aqui,

Porque é aqui

Que a chuva

Esfria

A lâmpada

De mercúrio

E o pneu

Roça o

Asfalto

Molhado

Fazendo barulho.

Em dimensões menores

Eu vejo o mais fundo:

Sou gigante

Para mim mesma.

Amores da vida

Da minha vida inteira

Enterram meus pés

No chão,

Explodem

Minha cabeça-coração,

Cicatrizam

Minhas feridas.

Guernica

É a paisagem

Então vista. 
DOIS POEMAS DA SÉRIE POEMETOS MINEIROS

\section{PARA VIOLA DE UMA CORDA SÓ}

I

As histórias

Da minha vida

Inseridas

$\mathrm{Na}$ parede,

Assim

Como o trem

Que partiu

Sem os olhos

Teus

II

Em terra estranha

Onde nasce gente feliz,

Difícil mesmo

É de avistar

Aqueles olhos

De frente,

Em meio

A tanta miséria... 


\section{LONG HAIR}

$\mathrm{O}$

E

Do

A

Sobre

Do

Os

Secaram

$\mathrm{E}$

$\mathrm{O}$

Para

Por que

Submersa

Este

Por

que

destino

Tua

Oh!

Das sete faces do amor?

fundo

orvalho cabelo

não

me

os

do

mar

ensinar

segredos

amor.

meus

olhos

não

da

recolhestes

de

tão

só,

em

poemas

sem

fim?

não

me

apresentas

face,

Deusa loura 
RAINHA DO MAR

Meu cabelo perfumado

Foi Mãe D’Água

Que emprestou.

Longos cabelos,

Longas histórias

Nas profundezas do mar.

Tzim-Tzum

Entre sol e mar

E a magia se revela

Sobre a areia fria

E chuvosa das tantas

Praias do mar.

É que tudo se encontra

Quase sempre

Neste mundo - vasto mundo

Em estado dormente

E somente o fogo e

A leveza do ar,

Que não penetram

Os desertos do mar, Nos apresentam

Kianda -

Deusa das águas

E dos mistérios

De amar. 
POEMA-FRUTA

\begin{tabular}{|c|c|c|c|c|}
\hline A & beleza & de & & fruta \\
\hline Independe & de & & seu & sabor. \\
\hline Enrolada & & em & & celofane \\
\hline dentro & de & uma & cesta & vime \\
\hline É & part & ularmen & & bela, \\
\hline Bela & $\mathrm{e}$ & cobi & da & também. \\
\hline Preciso & & & & libertá-la, \\
\hline Tirá-la & & do & & lugar, \\
\hline Enfim, & & & & comê-la. \\
\hline Qual & & o & & fim \\
\hline $\mathrm{Da}$ & & outra & & fruta \\
\hline Que & & & & amadurece \\
\hline $\mathrm{Em}$ & $\mathrm{um}$ & ca & & qualquer, \\
\hline Num & pirex & & da & cozinha? \\
\hline
\end{tabular}

Encontra-se

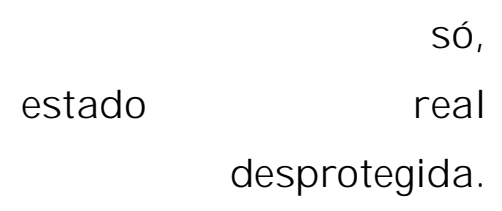

As

São

Em

Envolvidas

Por

A

Celofane seu

coisas

estado

uma

pele

de mais

de

fina

do lindas

aquelas

não-coisas,

casca;

sonho,

ilusões. 


\section{PASSAGEM PELA GRÉCLA}

Porque sou poeta

Em Roma, Goiás ou Creta,

Eu perco dinheiro,

Eu perco o emprego.

Porque sou poeta

Na Turquia, Bálcãs ou Síria,

Eu silencio, não desafio.

Porque sou poeta das normas

Ou das reformas,

Eu já não escolho,

Apenas proponho;

Anti todas as releituras

Ou necessidades,

Já não me inclino,

Só desatino.

Porque viver,

Quem sabe?

Para quem ensina,

Seja partir

Além dos profetas. 


\section{EGUÍVOCO}

A vejo

Sereia

De todos os mares

Mal sabia

A mãe

Rainha e

Sub versiva

De lares

A vejo

Princesa

De reinos aquáticos

Mal sabia

A proletária

Arroz e feijão

Em noites solitárias 
OS MEUS OLHOS DO MEU PAI

Recebi dos teus olhos

Ternos

Toda beleza

Pra se viver

Recebi dos teus olhos

Sábios

Toda coragem

Para só ser

Recebi dos teus olhos

Luz

O mapa das ruas

Por onde devo caminhar

Dos teus olhos

Amendoados

Castanhos e bem feitos

A cor da terra

E os desígnios

De amar

Recebi dos teus olhos

Mortos

Toda saudade

Que infinitamente

Terei que suportar. 


\section{PESCARIA ABSTRATA}

Pescar saudades no escuro do quarto

É garimpar você no mormaço da minha mente,

É sublimar-me em águas correntes, ondulantes,

Duradouras - águas do corpo humano.

Fisgar verdades que me maltratam,

É recaptular o meu mundo,

Tão antigo quanto todos os mundos.

Lembrar de coisas, de sub-títulos, obras escritas,

Palavras de mestres ou de prolixos...

Lembrar teu rosto -

Despedaçado dentro de mim.

Eu não gosto

De começos.

Os começos

São sem jeito.

Ansiosos.

Imperfeitos. 


\title{
PEQUENAS PERFEIÇÕES PERVERSAS
}

\author{
ao Peppy e Patrick
}

Meiguice e doçura

Transbordante

De feracidade.

Um quero-não-quero,

Um dengo eterno:

Eu te amo

Ou te arranho.

Ora sou fera,

Ora sou macho.

Rebelde

Nas mais imperfeitas

Horas.

As luvas de veludo,

As unhas perfuram

No momento

Mais inesperado.

Ora respiro

Profundo,

Ora quase durmo,

Mas com os olhos

Sempre despertos.

De dia adormeço,

À noite amanheço,

Já dizia o poeta...

Branco, malhado

Ou tigrado.

Por tudo ou por nada,

Aceso ou parado

É que sou forte,

O filho da mata,

Perfeito e amado,

O grande felino!

O gato 


\section{SEIVA}

Não posso pensar

Que sou una

Como árvore plantada

No chão

Sou alma livre

Solto espírito

Que se fragmenta

Vez ou outra

No meio

Dos teus

Braços

Abraços do tempo

Eterno

Etéreo momento 


\section{CHAMA}

Tenho as armas

De um corpo

Forte e bom

Para trazer-te

Sempre

Farto e fértil

Para perto

De mim

Tenho as armas

Marcadas

Fortes, definidas;

Mamas, ancas e pernas...

Domino este jogo,

Esta dança etérea,

Esta guerra ancestral.

Tenho a chama

Primeira

De todos os tempos

Que se chama você,

Que se chama

Você... 


\section{CONJUGADO}

Não acredito

Que estarás cansada.

Muda,

Não dirás nada.

Não acredito

Que estarás tranqüila,

Minha?

Nunca fostes minha...

Não acredito

Que ficarias sozinha

Em casa

Arrumada.

Arrumada

E vazia.

Não acredito

Que não acreditas

Em mim,

Senhor de nada,

Dono sem cão.

1 Doutora em Estudos Comparados de Literaturas de Língua Portuguesa (Faculdade de Filosofia, Letras e Ciências Humanas, Universidade de São Paulo). 